\title{
Memory Wars on the Silver Screen: Ukraine and Russia Look Back at the Second World War
}

\author{
SERHY YEKELCHYK \\ University of Victoria, Canada \\ serhy@uvic.ca
}

\begin{abstract}
In post-communist Russia the state has been supporting the production of historical films reflecting the official politics of memory, in which primacy is given to the victory in World War II. Often filmed in Ukraine, where the national cinema industry was nearly extinct until recently, these films project an imperial stereotype of modern Ukrainian identity as a fake and Ukrainian patriots as traitors. In contrast, the Ukrainian patriotic war narrative has only been reflected in straight-to-DVD films celebrating the nationalist insurgency. This article focuses on three recent films: two Russian films set in Ukraine during the war, which caused protests in Ukraine, and the first full-length Ukrainian war film to receive mass distribution, Mykhailo Illienko's Firecrosser (2012), interpreted here as an attempt to merge Soviet historical mythology with the Ukrainian one.
\end{abstract}

Key words: cinema, memory, nationalism, Russia, Ukraine, World War II

In the fall of 2012, following a decade-long hiatus, Ukraine submitted an official entry to the Academy Awards, Mykhailo Illienko's film Firecrosser. This film was not shortlisted in the "Best Foreign Film" category, but the very fact that a full-length Ukrainian film was presented for consideration serves as a good starting point for this article. The story of Firecrosser touches upon several larger themes, including the state of the Ukrainian cinema industry today, the search for a national compromise on issues of historical memory, attempts to respond to increasing ideological pressure from Russia, and the longing to be noticed by the West. Ironically, and perhaps inescapably, the Ukrainian cinematic answer has been taken for adjudication to Hollywood, the centre of the American film industry, which trumps national cinematic traditions and projects its one-dimensional image of other countries back to audiences in those same countries. This is precisely the model of cultural hegemony and stereotyping with which Ukrainian culture continues to struggle, particularly in its interaction with its former imperial master, Russia.

The official promotion of great-power nationalism and historical pride in post-communist Russia goes hand in hand with this state's efforts to re-establish its political and economic influence in the former Soviet republics. The Russian authorities clearly see cinema as an important vehicle for inculcating patriotism among their citizennry and swaying Russianspeakers in the "Near Abroad." The last decade in particular saw the production of numerous films applying Hollywood techniques to Russian history topics in a highly mythologised, 
patriotic version. ${ }^{1}$ One can argue that this cinematic version of history also has an obviously imperialistic, colonizing dimension because it claims for Russia some (heroic) historical events and (positive) fictional characters from the empire's other peoples. As we will see below, this is particularly true of Ukraine, an Eastern Slavic nation traditionally seen by Russians as their "younger brother." Whereas the modern states and national identities of the former empire's non-Russian nationalities are presented as fakes, their ancient heroic pasts are still regarded as "Russian," as are, of course, their true selves. The representation becomes more complex in the portrayal of twentieth-century conflicts involving a direct clash between a separate national identity and the common imperial one, such as World War II. In such cases, the producers of the Russian cultural myth introduce "good" and "bad" Ukrainians or show the "bad" ones discovering their "true" Russian selves. Cultural representations of Ukraine and Ukrainians are particularly important in the structure of Russian historical mythology because of the perceived close ethnic affinity and the many events from Ukrainian history that are traditionally interpreted as "heroic pages" of Russian history. No other post-Soviet nation challenges-by its very existence-Russian cultural myths so profoundly; not even the third East Slavic country, Belarus, which in any case emphasises its affinity with Russia.

The Great Patriotic War, as World War II is still known in Russia, remains at the heart of the official politics of memory; it is the principal discursive site where Russia's historical self-image is constructed. No other historical subject has generated such a massive filmography in postcommunist Russia. ${ }^{2}$ State agencies and Kremlin-friendly oligarchs provide generous funding for patriotic films about the war. In general, the Russian state is actively involved in the national cinema industry by supporting "deserving" film projects through the Ministry of Culture and the Federal Foundation for Social and Economic Support of National Cinematography (the "Cinema Fund"). In 2012 the Russian federal budget allocated 5.9 billion rubles (US\$188 million) for these purposes - a significant amount given that a typical film budget in Russia is only several million. ${ }^{3}$ Interestingly, very few Russian World War II films recoup their production expenses. Even the two recent, big-budget, and highly publicised war films completing Sergei Mikhalkov's trilogy that began with his Oscar-winning Burnt by the Sun, Exodus (2010), and Citadel (2011) flopped at the box office. However, the Russian film critic Daniil Dondurei has argued that the state supports war films with a clear understanding that they are not made to make money but to reach out to the public through repeated reruns on television. ${ }^{4}$ In other words, the Russian authorities regard the production of such films as an important propaganda measure for both the domestic audience and the former Soviet republics, where film distribution networks are often controlled by Russian companies, and Russian films are still widely shown in cinemas and on television. The foreign-policy angle is important because the current "memory wars" between Russia and other post-Soviet states most often focus precisely on differing interpretations of the war, in particular the Red Army's "liberation" and various national insurgencies. ${ }^{5}$ In the case of

\footnotetext{
${ }^{1}$ See S. M. Norris, Blockbuster History in the New Russia: Movies, Memory, and Patriotism, Bloomington, Indiana University Press, 2012 and J asmijn Van Gorp, "Inverting Film Policy: Film as Nation Builder in Post-Soviet Russia, 1991- 2005," Media, Culture, and Society Vol. 33, No. 2, 2011, pp. 243- 58.

2 See, more recently, T. Smorodinskaya, "The Fathers' War Through the Sons' Lenses," in Cinepaternity: Fathers and Sons in Soviet and Post-Soviet Film, Helena Goscilo and Yana Hashamova (ed.), Bloomington, Indiana University Press, 2010, pp. 89- 112; Elena Baraban, "Forget the War: Wartime Subjectivity in Post-Soviet Russian Films," Canadian Slavonic Papers 54, Nos. 3- 4 (September- December 2012), pp. $295-318$.

${ }^{3}$ Nevafilm, "The Film Industry in the Russian Federation: A Report for the European Audiovisual Observatory, November 2012," p. 8 <http:// www.obs.coe.int/ oea publ/ eurocine/russianfilmindustry nevafilm2012.pdf.en>, accessed 23 September 2013.

4 D. Dondurei, "Ne otkhodia ot kassy," Itogi, No. 49, 2010, pp.78- 79.

${ }^{5}$ See for example recent works published in Russia: Gennadii Bordiugov, "Voiny pamiati" na postsovetskom prostranstve (Moscow: AIRO-XXI, 2011); G. Kasianov and A. Miller, Rossiia- Ukraina: Kak pishetsia istoriia, Moscow, RGGU, 2011, Chapter 6.
} 
Ukraine, where society is split on these issues, Russian cinematic propaganda has also becomea weapon in internal political struggles.

Unlike in Russia, in Ukraine the significance of World War II for national history remains a highly divisive issue. The cult of anti-Soviet nationalist insurgents is by now well established in the western part of the country, whereas in central and eastern Ukraine the Soviet narrative of the war has remained unchallenged, until recently. The administration of President Viktor Yushchenko (2005-10) made the first serious attempt to recognise the fighters of the Ukrainian Insurgent Army (UPA) as war veterans alongside those Ukrainians who served in the Red Army, as well as to elevate the nationalist leaders Stepan Bandera and Roman Shukhevych to the status of national heroes in a very literal sense, by awarding them the Hero of Ukraine medal. ${ }^{6}$ Even under Yushchenko, however, the state provided only sporadic and insignificant financial support for the production of patriotic historical films. His successor and political opponent, President Viktor Yanukovych, is even less likely to encourage the nation-wide rehabilitation of the Organization of Ukrainian Nationalists (OUN), because he relies on the support of the eastern Ukrainian electorate, which embraces the Soviet narrative of the Great Patriotic War. Whereas under Yushchenko Russian films could be banned for their negative representations of Ukrainians, this has not happened under Yanukovych.

In addition to being a significant market for the distribution of Russian films, Ukraine also serves as a production base for them. It is cheaper for Russian producers to hire facilities and personnel in Ukraine, where the native film industry has become practically extinct, yet Sovietbuilt studios remain. According to Ukrainian newspaper reports from 2011, the three film studios in Kyiv, Odessa, and Yalta have been surviving primarily by renting their facilities for the filming of various Russian films as well as Russian and some Ukrainian TV shows. (There is also some agricultural production taking place on the land surrounding the Odessa Studios, including the commercial growing of organic melons and other produce. ${ }^{7}$ ) It is no wonder that Ukrainian actors and technical personnel covet invitations from Russian film producers. Ironically, they often find themselves playing the very roles that fit the traditional Russian stereotype of Ukrainians as their lazy, funny, singing-and-dancing younger brothers or murderous, pro-Nazi nationalists; the latter depicition reflecting the more sinister stereotype of Ukrainians that has been portrayed in recent Russian films about World War II. Ostap Stupka, the artistic director of Kyiv's Ivan Franko Ukrainian Drama Company, for one, has been typecast in such roles. Younger directors and cameramen also eagerly seek employment in the Russian cinema industry. In May 2011 the main state-owned channel in Russia, RTR-Rossiia, marked Victory Day by showing a mini-series called Roasted Hare, Berlin Style, which is set during the war and filled with negative Ukrainian protagonists. Under Yanukovych this channel, once banned in Ukraine, has once again been included in most cable television packages, and Ukrainian audiences have thus been able to view this newest work by the Ukrainian director Serhii Krutin, who studied under the patriotic director Mykhailo Illienko at the Kyiv Institute of Theatre, Cinema, and Television. ${ }^{8}$

When continued cultural hegemony by a former imperial master is infused with economic attraction, "speaking back to the empire" becomes even more challenging, as confirmed by the history of Ukrainian cinema in the last decade. Yuri Illienko's whimsical film, A Prayer for

\footnotetext{
${ }^{6}$ See D. R. Marples, Heroes and Villains: Creating National History in Contemporary Ukraine, Budapest, Central European University Press, 2008; E. Narvselius, 'The 'Bandera Debate': The Contentious Legacy of World War II and Liberalization of Collective Memory in Western Ukraine," Canadian Slavonic Papers Vol. 54, Nos. 3- 4, 2012, pp. 469- 90; and Ararat L. Osipian, "Regional Diversity and Divided Memories in Ukraine: Contested Past as Electoral Resource," East European Politics and Societies Vol. 26, No. 3, 2012, pp.616- 42.

${ }^{7}$ Segodnya, 9 September 2011; KP v Ukraine, 23 J une 2011.

8 Den, 13 May 2011.
} 
Hetman Mazepa (2002), portraying colonial domination symbolically as sexualised violence, caused a scandal and was banned in Russia, primarily because of a homosexual rape scene involving Tsar Peter I and a Russian soldier. However, the Russian ban was largely symbolic because this complex allegorical film was not distributed in Ukraine either, not even in arthouse theatres. ${ }^{9}$ In 2009 Russia marked the 200 ${ }^{\text {th }}$ anniversary of Gogol's birth by releasing an expensive historical costume drama, Taras Bulba, with its patriotic message skilfully redefined by moving Bulba's "Russian soul" speech to the opening scene. The Ukrainian cinema industry could only respond with a cheaply produced straight-to-DVD version, The Tale of Taras Bulba, based on the play version of the novel as staged by a provincial theatre. But it could not rival the splendor of the Russian version, which also featured in the title role Ukraine's preeminent actor and former minister of culture, Bohdan Stupka. Needless to say, it was the Russian film that enjoyed a repeat run on Ukrainian television.

Characteristically, A Prayer and The Tale tried to offer a Ukrainian version of history on the topic that is at the very core of the traditional foundational myth of the national past: Cossack glory. Providing a direct response to the Russian cinematic mythology of World War II has been more difficult, and not just because the Ukrainian population continues to be split on these issues. With funding from nationalist organizations and individual sponsors in the Ukrainian diaspora, the director Oles Yanchuk has made several films about anti-Soviet, nationalist heroes: biopics of Stepan Bandera (Atentat, 1995) and Roman Shukhevych (The Undefeated, 2000) and a film about one unit of the Ukrainian Insurgent Army (The Iron Company; the official English title was The Company of Heroes, 2004). A leading Ukrainian film critic, Oleksandr Rutkovsky, has compared these films to the worst examples of Soviet films about Bolshevik leaders and wartime partisans, which Communist Party activists were forced to watch after ideological conferences. ${ }^{10}$ Yanchuk's films never made it to theaters and, at best, were screened once or twice on Ukrainian television's least popular channels. However, Yanchuk has indicated in his interviews to the newspaper Halychyna that the regional television channel, Halychyna, which is available in Ukraine's westernmost regions, broadcasts them regularly. According to him, wherever the Halychyna channel is received, schoolchildren know his films. ${ }^{11}$ Of course, this indicates that films celebrating radical nationalist heroes reach mass audiences only in western Ukraine, where they once operated and are already being revered under the rule of a right-wing, nationalistic local administration. Here, no antidote to Russian mythology is needed.

Perhaps more importantly, all three films focus disproportionately on the postwar period, portraying the Ukrainian guerrillas on the defensive against the invading Soviet army and security police personnel (even if the action takes place partly in Poland or Czechoslovakia, as it does in the latter two films). It is much easier for audiences to take sides in such a setting, which would not have been the case with the portrayal of the bloody and chaotic, sometimes fratricidal, struggles of World War II that would also come in the same package with such difficult themes as the Holocaust and the Polish-Ukrainian violence in Volyn. Characteristically, none of the three films shows the nationalist guerrillas attacking Red Army units, let alone Soviet functionaries or civilians; but two of them include nearly identical scenes of the UPA's wartime surprise attacks on Nazi troops. The former topic remained too sensitive to handle even in a film intended primarily for a western Ukrainian audience.

\footnotetext{
${ }^{9}$ For an analysis of this film see Maryna Romanets, "Postcolonial On/ scenity: The Sexualization of Political Space in Post-independence Ukraine," Canadian-American Slavic Studies Vol. 44, Nos. 1- 2, 2010, pp. $178-99$.

10 Dzerkalo tyzhnia, 18 November 2000.

11 Halychyna, 31 March 2012.
} 
Russian filmmakers did not display any such sensibility. In 2010 Ukraine's Ministry of Culture banned the distribution of the Russian war fantasy film, We Are from the Future-2. Its prequel, We Are from the Future (2008), was in most respects a typical, well-crafted Russian World War II film with interesting intertextual references to classic Soviet films. What set it apart, however, was the time-travel component. Four young men from St. Petersburg, none of them particularly patriotic, and one even a neo-Nazi of sorts, travel to a World War II battlefield as "black archeologists" to dig up various paraphernalia for resale. Magically transported to 1942, they learn in battle how to love the Motherland. Like so many Russian war films, this film included a negative Ukrainian character speaking Ukrainian, but in a twist on the predominant stereotype, he is the NKVD guard rather than a nationalist or Nazi helper.

In the sequel, however, the Ukrainians' role in World War II and the divergent Ukrainian and Russian historical memories of the war are positioned front and center. Made by another director and with some of the principal actors replaced, We Are from the Future- 2 was much less successful artistically, but it became a sensation because of its banning in Ukraine. The sequel's plot features the same four friends traveling to western Ukraine to take part in a battle re-enactment at Brody. This 1944 battle being the only significant military engagement of the SS Galicia Division against the Red Army, the stage seems set for a very physical clash of two heroic historical narratives. ${ }^{12}$

However, such a clash happens before the re-enactments, at an outdoor dancing party, where firefighters have to break up a fight between the Russians and Ukrainians with jets of cold water. Significantly, the western Ukrainians portrayed in the film are never referred to as "Ukrainians," only as "Galicians," in an attempt to separate them from the implicitly more pro-Russian "Ukrainians." In the present, they are represented by a spoiled, physically unimpressive Seryi ("The Grey One," portrayed by Dmytro Stupka, the son of Ostap and grandson of Bohdan Stupka, and also a member of the Ivan Franko Ukrainian Drama Company), the son of a Ukrainian parliamentarian, who drives around in a Hummer in the company of his Ukrainianspeaking sidekick. Whenever something is not to his liking, Seryi threatens in Ukrainian to call his daddy on his expensive cell phone to straighten out his problems. Predictably, the two Ukrainians and the four Russians are transported into the past, to 1944, in order to undergo an ideological transformation in which they experience "true" history first-hand.

Interestingly enough, the six visitors from the future do not find themselves in the middle of the battle they were re-enacting, that is the SS Galicia Division's clash with the Red Army. Instead, they are instantly captured by a detachment of the Ukrainian Insurgent Army headed by a moonshine-drinking and bloodthirsty warlord (Ostap Stupka), who wants to test the captives' allegiances by making them execute in a nearby ravine a group of peasants, including women and children, for allegedly helping the Soviets. When the time travelers are unwilling to do so, the Ukrainian insurgents machine-gun the peasants and then order the two Ukrainian-speaking strangers to kill the four Russian speakers. A deus ex machina, in the form of a sudden German bombing attack, sends the six on new adventures that by the end of the film lead them to join a small Red Army unit trying to stop a massive German counterattack. It is noteworthy, however, that the filmmakers clearly wanted to lump together all the Ukrainian armed formations of the World War II period and brand them as cold-hearted killers of their own civilians.

In a highly symbolic counterpoint, the director makes Seryi's sidekick Taran, who earlier in the film had knocked down a small monument at a grave of Soviet soldiers, meet these very same

12 On the SS Galicia Division's subsequent lionization in the Ukrainian diaspora and in western Ukraine, see Olesya Khromeychuk, 'The Shaping of 'Historical Truth': Construction and Reconstruction of the Memory and Narrative of the Waffen SS ‘Galicia’ Division,” Canadian Slavonic Papers Vol. 54, Nos. 3-4, 2012, pp. 443- 67. 
soldiers just before their mortal combat in the same forest grove, when he is saving the newborn baby of a Soviet captain and a military nurse. Kneeling before the soldiers with a baby in his arms, Taran becomes a Pietà-like figure, as though replacing the memorial he had destroyed. Less subtle is the transformation of Seryi, who, after returning to the "present," switches to Russian and asks the re-enactment participant dressed as the Red Army officer for his (inexpensive) cell phone in order to call his mother, rather than his father, the parliamentarian. He has clearly rediscovered his "true" Russian self.

J ust before the film's release in Russia in February 2010, Ukraine's Ministry of Culture blocked its simultaneous release in Ukraine as a work "promoting ethnic strife and demeaning the national pride of Ukrainians."13 February 2010 was the last month of Viktor Yushchenko's presidency, but this ban proved difficult to undo even after the pro-Russian administration of Viktor Yanukovych came to power. In November 2010 one of the leading Ukrainian television channels, ICTV, announced its intention to broadcast We Are from the Future 2 in its coveted 9 p.m. film slot, but had to retract this decision after vocal protests from some Ukrainian activists. (The planned broadcast also coincided with the annual, week-long commemorations of the Holodomor, when Ukrainian citizens honour the victims of Stalin's manmade famine of 193233. ${ }^{14)}$ The channel finally showed the film in May 2012.

In general, the Yanukovych administration has tried to create the impression that it has been pursuing an independent policy in matters of film distribution rather than just following the Russian line. In March 2012 Ukraine's Ministry of Culture banned another Russian film, August 2008, which tried to put a human face on the Russian invasion of Georgia's South Ossetia region. ${ }^{15}$ However, Yanukovych followed Russia's example in creating the State Program on the Production and Distribution of National Films in 2011 and in the followingyear, the Council for the Promotion of National Cinema. To a large degree, these innovations were aimed at improving the administration's image in the sphere of Ukrainian culture, as well as controlling the distribution of state grant funds. Still, the amounts involved (95 million hryvnias, or US\$ 12 million in 2011) have been comparatively insignificant, and no projects on contentious historical topics have been funded thus far. ${ }^{16}$

Meanwhile, in May 2012 another controversial Russian war film from Andrei Maliukov, the director of We Are from the Future 2, opened in Ukraine. The Match became even more contentious because the film's subject matter was life in Kyiv under the German occupation during World War II. The film was filmed entirely on location in Kyiv, Kharkiv, and Vasylkiv, a city near Kyiv, and its credits acknowledge the active participation of Ukrainian technical personnel, actors, and numerous extras. Oles Sanin, one of the most gifted, younger Ukrainian directors, worked on this project as an assistant director. Ukrainian actors were cast in many secondary roles, and they also played the two principal villains of the film: the policeman Deshchenia (Ostap Stupka) and the city mayor under Nazi rule, Barazii (Stanislav Boklan from Kyiv's Molodyi Theater). Essentially, The Match is a prime example of the Russian cinema industry using Ukraine as a filming location and Ukrainians as a labour force for the production of Russian historical myths. Moreover, in this case it was the Russian version of wartime events in Ukraine that was being filmed in Ukraine for subsequent consumption by Ukrainian as well as Russian audiences.

\footnotetext{
13 Kievskie vedomosti, 19 J anuary 2010; Segodnya, 16 February 2010.

14 Den, 24 November 2010.

${ }^{15}$ Dzerkalo tyzhnia, 11 March 2012.

16 Segodnya, 3 September 2011; Den, 15 February 2012.
} 
As is often the case with contemporary Russian historical myths, the one that The Match reinforces is a refurbished version of the old Soviet myth. The film lionises the soccer players from the Dynamo Kyiv team who, as the official Soviet version goes, won a "death match" in August 1942 against a team of German air defence amateurs and were consequently executed by the Nazis. Subsequent research after the collapse of the USSR revealed that in fact the Ukrainian team from Kyiv had won many games against German and Hungarian military amateur teams. Their team, called Start, included only five players from the prewar Dynamo Kyiv. The Gestapo arrested them because it had received a denunciation that the Dynamo players had all served formally in the NKVD, the Dynamo club being a sports arm of the NKVD. The players were executed together with other POWs much later, in the spring of 1944, apparently as random hostages in retribution for an attempt on the life of a German police official. ${ }^{17}$ Still, the legend has had a long life in popular memory and been fuelled by two Soviet films on this topic, as well as books and monuments. The filmmakers chose to end the film with a victory over the Germans on the soccer field followed by a story line text informing viewers that in 2005 the German prosecutor's office did not find a direct link between the win and the executions. Viewers were thus being invited to form their own opinion based on the film's heroic pathos rather than the former enemy's denial.

If the makers of The Match were intent on renewing Soviet patriotic mythology, they did so in full awareness of more recent Russian-Ukrainian political tensions. There are actually two games and two victories of Start that receive approximately equal coverage in the film, the first one not over the Germans but another Kyivan team called Rukh. "Rukh" is the Ukrainian word for "movement," and there was indeed such a soccer team in wartime Kyiv, but to Russian film audiences the term denotes the name of the Ukrainian popular front from the late 1980s, which they associate with minority nationalism leading to the Soviet empire's collapse. In the film the Rukh team is an explicitly "Ukrainian" team as opposed to the "Soviet" Start. Rukh is organised by the film's Ukrainian villain, the mayor's advisor on sports and culture, who is played by the Kyivan actor Oleksandr Kobzar. The filmmakers preserved his protagonist's real Russiansounding name, Georgii Shvetsov, but portrayed him as a Ukrainian nationalist. His boss, the mayor of Kyiv, who looks and speaks like President Yushchenko, is even more of a nationalist. The mayor says at some point that the leadership (provid) of the Organization of Ukrainian Nationalists assigned him to this post. This is probably historically incorrect, because the OUN did not exercise control over the Germans' appointments of senior figures in Kyiv's municipal administration, but it serves well the film's overall purpose of connecting present-day Ukrainian activists to wartime Ukrainian nationalists and through them, to the Nazis. The mayor's name, Barazii, is an obvious reference to the third Nazi-appointed mayor of Kyiv, Volodymyr Bahazii, who was a member of the Melnykite wing of the OUN, executed by the Germans in the summer of 1942. ${ }^{18}$ In the film the mayor is obsessed with Anna, the lover of the main positive protagonist, the goalkeeper Nikolai Ranevich, and forces her to live with him in exchange for saving Ranevich's life. Deshchenia (Ostap Stupka), Ranevich's Ukrainian-speaking neighbour in the communal apartment, is the most morally reprehensible character in the film. He steals from his neighbours, peeps at their women, and makes derogatory remarks about J ews. Under Nazi rule he ends up as a policeman who takes part in executions. (One wonders what Stupka was thinking when, during an interview, he defended his decision to accept this role by saying that he would be portraying "quite an interesting and colourful character."19)

\footnotetext{
${ }^{17}$ See V. I. Prystaiko, Chy buv "match smerti"?: Dokumenty svidchat, Kyiv, EksOb, 2006.

18 See K. Berkhoff, Harvest of Despair: Life and Death in Ukraine under Nazi Rule, Cambridge, Mass., Harvard University Press, 2004, pp. 51- 52.

${ }^{19}$ Gazeta po-kievski, 3 J une 2011.
} 
Thus, if audiences are encouraged to identify with "our people" from the Start team, then the first enemy whom "our people" defeat is the Ukrainian team. The sole "ideological enemy" is the Ukrainian politician, who steals the main protagonist's lover. The film also shows Ukrainianspeaking auxiliary policemen wearing blue-and-yellow armbands and beating up J ews in the city and later helping the Germans herd them into the killing field of Babi Yar. Even longer and more elaborate is the scene in Babi Yar, partly filmed in slow motion, in which Ukrainian policemen and the German SS are brutally killing patients from the city's psychiatric hospital. This is historically incorrect because the mentally ill were actually gassed by German Einsatzgruppe personnel in a gas van on the hospital grounds, but this distortion of fact was apparently important for the filmmakers' agenda. ${ }^{20}$ The acts of fatally bludgeoning the helplessly insane and then shooting them one by one symbolically represent pure violence devoid of ideology, an absurdly sadistic slaughter of childlike individuals, of which only the SS and Ukrainian policemen were capable. The Russian-speaking female doctor witnessing this massacre loses her mind.

In general, all the film's negative protagonists speak Ukrainian, while all the positive ones speak Russian. The only exception, the elderly Ukrainian-speakingyard keeper who helps Anna savea J ewish girl, is clearly a gesture aimed at offsetting this obvious language encoding of good and evil. Significantly, the only Ukrainian-speaking player on the Start team, Mykola, switches to Russian during the "death match," and his teammates start calling him "Nikolai." When Mayor Barazii senses that the Germans no longer trust him and he decides to save Anna by sending her away, the moment finally comes for him to switch to Russian with her, because it is his "true self" that is now speaking in the face of death.

The controversy around The Match erupted even before its release in Ukraine. A slight delay in the issuance of official approval made headlines in the world media, in part because of the buildup to the Euro 2012 games slated to take place in Ukraine and Poland that summer. The Independent published, somewhat prematurely, an article entitled "Ukraine Blocks Football Film over Nazi Death Match."'21 In fact, the distribution permit was issued before the intended opening date. However, the police had to be called in when members of the right-wing Svoboda Party protested at the premiere held in Kyiv's main cinema theater Ukraina. Among the detained protestors were the two sons of the late director Yuri Illienko, who made A Prayer for Hetman Mazepa. ${ }^{22}$ In the western Ukrainian city of Rivne the municipal authorities sided with the Ukrainian cultural and political organizations protesting the film's opening and provided 10,000 hryvnias to compensate the city's main cinema theater for breaking the distribution agreement. $^{23}$

At the time when the sons of Yuri Illienko were demonstrating at the opening of The Match, the director's brother Mykhailo completed Firecrosser (2012), the first Ukrainian film to offer a meaningful national alternative to the Russian mythology of World War II. Firecrosser not only became the first Ukrainian film to receive mass distribution nationally. It also grossed more per copy on the thirty copies that were printed than an average Hollywood blockbuster would on

\footnotetext{
20 A. Kuznetsov, Babii Iar: roman-dokument, Kyiv, Radianskyi pysmennyk, 1991, p. 113.

21 The Independent, 20 April 2012.

22 'V Kieve pytalis sorvat pokaz filma 'Match,' zaderzhano okolo 20 natsionalistov"

$<\underline{\mathrm{htp}}$ :// focus.ua/ society/ 228948/>, accessed 23 September 2013. The younger of the Illienko brothers, Andrii, was elected to the parliament in 2012 as number five on the Svoboda list. He heads the party's organization in Kyiv and has co-ordinated the party's national campaign against what it calls "illegal migration to Ukraine."

23 “U Rivnomu domohlysia zaborony filmu pro 'match smerti,"' Novyny TSN, 27 April 2012

$<$ http:// tsn.ua/ ukrayina/ u-rivnomu-domoglisya-zaboroni-filmu-pro-match-smerti.html>, accessed 23 September 2013.
} 
approximately fifty to seventy copies in Ukraine. ${ }^{24}$ Ukrainian intellectuals also welcomed the film. Oksana Zabuzhko, a leading literary figure, declared that the film's main protagonist represented nothing less than the culmination of Ukraine's search for a new national hero. ${ }^{25}$

The film's main hero merits a closer look. The filmmakers claimed that they based the plot line on a true story about the Soviet Air Force pilot Ivan Dotsenko (sometimes spelled Datsenko), an ethnic Ukrainian who was decorated for his wartime exploits with the gold star of the Hero of the Soviet Union. German air defenses shot down Dotsenko's bomber over the western Ukrainian city of Lviv on 19 April 1944, and its entire crew was presumed dead. However, in the 2000s some Ukrainian journalists created an attractive legend that Dotsenko had survived and after the war somehow became an aboriginal chief in Canada. They cited various versions of a story recounted on many occasions by the famous Soviet Chechen dancer Makhkmud Esambaev, who allegedly met a Ukrainian-speaking aboriginal chief in Canada during the World's Fair in Montreal in 1967. ${ }^{26}$ However, Esambaev died in 2000, and no one could confirm or disprove any versions of the legend ascribed to him. In any case, the filmmakers renamed their main protagonist Ivan Dodoka, which allowed them to give free rein to their imagination. The narrative they invented, however, is very telling in that it suggests a new version of the national myth. Instead of attempting to dismiss wholesale the well-entrenched Soviet cult of the Red Army's "liberation," they modify it. Their hero is not an UPA fighter but a Soviet Ukrainian who takes on the Stalinist system.

In the film, the young Ivan's Ukrainian identity is established through references to the famine of 1932- 33 and popular religion; his father is hiding the family icons in the same alcove where he has concealed some grain to feed his family. The filmmakers also present his distinguished service in the Red Army through a whimsical prism typical of the Ukrainian "poetic school" of late Soviet cinema. Dodoka is shot down not when he is bombing a western Ukrainian city, but while trying to help a flock of storks get across the front line. The whimsical elements quickly become surrealistic, if not blatantly absurd. As it turns out, Ivan, who comes from a long line of Cossack sorcerers (kharakternyky), owes his flying skills to a Ukrainian magical formula. Another Ukrainian incantation repels wild animals. A further effort to merge folk poetics with contemporary mass culture turns into a caricature when Ivan transforms himself into a werewolf. Captured first by the Germans and subsequently imprisoned in the Stalinist Gulag, he escapes by somersaulting over his own belt (which must be well worn), and disappears into the woods as a wolf.

As Ivan (played by the Kyivan actor Dmytro Linartovych, who turns in a great performance) makes his way through Siberia to North America in a series of hard-to-believe coincidences, he allegorically connects two Ukrainian myths: the Soviet one of wartime heroism and the diasporan one of finding refuge in the free world. In the film's finale he reconciles himself to the prospect of never seeing Ukraine and his family again and starts building a Ukrainian hut in the isolated First Nations village that gave him refuge. He is dressed in aboriginal clothes, but wears his gold star of the Hero of the Soviet Union. The filmmakers were not interested in showing him joining the organised Ukrainian diaspora because his flight from the Stalinist reality could only be directed into a poetic space that was close to nature. Yet, it was important for them to establish his separation from post-Stalinist, Soviet Ukrainian identity. In one of the flash-

\footnotetext{
24 Stanislav Prytula, "Iak robytsia ukrainske kino," <http:// polit.ua/ articles/2013/ 02/ 15/ prytula.html>, accessed 23 September 2013.

25 Oksana Zabuzhko, "Vyklykannia heroia, abo khto proishov kriz ruiny,” broadcast by the Ukrainian Service of Radio Liberty on 1 March 2012; located at <http:// www.radiosvoboda.org/ content/ article/ 24500860.html>, accessed 23 September 2013.

26 See, e.g., Ukraina moloda, 19 J anuary 2012, and Halychyna, 26 J anuary 2012.
} 
forwards earlier in the film, Ivan is riding a horse when he encounters a visiting Soviet delegation inspecting a Canadian corn farm (a reference to the Khrushchev period); the delegation includes the same Ukrainian NKVD officer who had once tried to kill him. When the officer asks Ivan in Russian, "Comrade Indian, are you from around here?" he answers in the intentionally archaic Ukrainian peasant dialect, "From here (tuteishyi)." Indeed, the new hero exists in a poetic discursive space that is as far from Soviet Ukraine as it is from a Ukrainian enclave in some large North American city.

Firecrosser represents an interesting Ukrainian answer to Russian historical mythology as disseminated by contemporary Russian cinema. The film's success at the box office also indicates that it resonates well with the expectations of the post-communist Ukrainian public, which is still not ready fully to accept the side of the UPA fighters and the SS Galicia Division in the post-Soviet "memory wars." The public probably also enjoyed the heroic, if surrealistic, plot that contrasts with the recent overload of victimhood narratives in Ukrainian memory politics. However, one can argue that Firecrosser is also a problematic response to Russian imperial mythologies. In contrast to the Hollywood techniques of Russian war films, Firecrosser uses the language of Ukrainian poetic cinema from the 1960s, a language that is decidedly unmodern and surrealistic, and one that younger audiences do not read easily or perhaps read too literally when a symbolic interpretation is called for. ${ }^{27}$ Its main hero moves from one liminality to another: from the poetic, natural world of Ukrainians to that of North American native peoples - and also at a time when the latter are an oppressed minority in their country. Indeed, the chief of the tribe that Ivan joins tells him about encroachments on their traditional lands.

The film also follows the well-established tradition of Soviet cinema in making the hero's nemesis, the NKVD officer Stepan, a fellow Ukrainian from the same village, who also desires the same woman. Of course, in Soviet films the Ukrainian hero would be opposed to a "bad" Ukrainian nationalist, but the overall model remains intact. Ivan's best friend is his former pupil from the flying school, a Russian pilot named Kolya Yeremin (played by the Russia-based actor Artem Antonchenko); the woman he loves is Tatar (played by Olga Grishina, an actress of Kyiv's Russian Drama Theater, whose film career has been primarily in Russian television series). It is almost as though the old Soviet prescription that a war film should prove the Red Army's "internationalism" is still valid. For Ivan, Ukraine remains a childhood memory, part of his heritage rather than the land for which he is fighting against the Nazis or the Soviets. In other words, the film combines the negative image of Soviet rule in Ukraine with a generally positive take on the Soviet war effort. Within its poetic portrayal of Ukrainian identity, the fundamental structures of imperial mythologies remain unchallenged.

However, one cannot underestimate the importance of this first attempt at making a Ukrainian war blockbuster. After nearly two decades of Ukraine serving as a production base for Russian films replicating Russian historical mythology, Firecrosser was accorded a warm welcome by both the general public and intellectuals, who thus signalled their readiness to embrace an alternative Ukrainian vision. Earlier, small-budget Ukrainian films celebrating the nationalist insurgents could not generate the same interest nationally, but the public had also grown tired of the Russian cinematic representation of modern Ukrainian identity as false or even treasonous. However, the limitations of Firecrosser stemmed from the same source as its success: the use of the familiar Soviet narrative of the war as a starting point.

\footnotetext{
27 The film historian Bohdan Y. Nebesio has argued that the return in the last years of the Soviet Union to the interrupted tradition of the "poetic school" was in fact a step back limiting the development of modern Ukrainian cinema. See his "Questionable Foundations for a National Cinema: Ukrainian Poetic Cinema of the 1960s," Canadian Slavonic Papers, Vol. 42, No. 1-2, 2000, pp.35- 46.
} 